\title{
Guidelines for User Driven Service and E-Service Innovations
}

\author{
Scupola, Ada
}

Published in:

Proceedings of ITAIS 2013, X Conference of the Italian Chapter of AIS , Empowering society through digital innovations

\section{Publication date:}

2013

\section{Document Version}

Early version, also known as pre-print

Citation for published version (APA):

Scupola, A. (2013). Guidelines for User Driven Service and E-Service Innovations. In Proceedings of ITAIS 2013, X Conference of the Italian Chapter of AIS , Empowering society through digital innovations AIS Association. http://www.cersi.it/itais2013/

\section{General rights}

Copyright and moral rights for the publications made accessible in the public portal are retained by the authors and/or other copyright owners and it is a condition of accessing publications that users recognise and abide by the legal requirements associated with these rights.

- Users may download and print one copy of any publication from the public portal for the purpose of private study or research.

- You may not further distribute the material or use it for any profit-making activity or commercial gain.

- You may freely distribute the URL identifying the publication in the public portal.

Take down policy

If you believe that this document breaches copyright please contact rucforsk@kb.dk providing details, and we will remove access to the work immediately and investigate your claim. 


\title{
Guidelines for User Driven Service and E-Service Innova- tions
}

\author{
Ada Scupola \\ Roskilde University, Department of Communication, Business and Information \\ Technologies, Hus 44.3, DK-4000 Roskilde Denmark \\ ada@ruc.dk \\ Published in Proceedings of ITAIS 2013, X Conference of the Italian Chapter \\ of AIS , Empowering society through digital innovations, Università \\ Commerciale Luigi Bocconi, Milan (Italy), December $14^{\text {th }}, 2013$, Proceedings \\ ISBN: 978-88-6685-007-6
}

\begin{abstract}
The purpose of this article is to provide a set of guidelines consisting of tools and steps to be used to design service innovations by involving the users. The guidelines are based on an understanding of the service development process as a linear stage process as described by Alam (2002) and user roles as described by Nambisan (2002). The tools and steps are illustrated through the way they have been applied to develop and design service and eservice innovations in the case of Roskilde University Library.
\end{abstract}

Key Words: Services, E-services, Design, Innovation, User Involvement

\section{Introduction}

Service innovation and design is becoming a very popular subject both in academia and in the business world, especially in consulting companies. Bitner et al. (2008) state that organizations that are most successful in providing new services "prepare and move systematically (and often iteratively) through a set of planned stages from the establishment of clear objectives, to idea generation, to concept development, service design, prototyping, service launch, and customer feedback" (Bitner et al., 2008 , p. 4). In the earliest contributions on service design (Shostack 1982; Shostack 1984), the activity of designing service was considered as part of the domain of marketing and management disciplines. Shostack (1982), for instance proposed the integrated design of material components (products) and immaterial components (services). This design process, according to Shostack $(1982 ; 1984)$ can be documented and codified using a "service blueprint" to map the sequence of events in a service and its essential functions in an objective and explicit manner. Similarly, previous literature on service innovation and design (NSD) (e.g. Alam and Perry, 2002; Alam, 2002; Alam, 2006; Scupola and Nicolajsen, 2010) suggests that service innovation 
has to be anchored in the organization's strategy in order to succeed (e.g. Bitner et al., 2008). A new trend within service innovation and service design is the direct or indirect involvement of the users in such processes (e.g. Alam and Perry, 2002; Magnusson, 2003; Magnusson et al., 2003; Matthing et al. 2004; Scupola and Nicolajsen, 2013). User involvement may contribute to service innovations that are more in line with the user needs and wants and may result in increased customer satisfaction, services with less point of failures and at the very end an increased competitive advantage of the company. Given this background, the purpose of this article is to develop and provide a set of guidelines that can be used to involve the user in the service innovation or design process.

The article is structured as follows. The introduction presents the background of the chapter. The second section briefly presents the theoretical background including conceptual definitions of services and e-services, user involvement in the service innovation and design process as well as the tools that can be used in such a process. The third section illustrates how the tools were used in Roskilde University library to involve users in the innovation of the services offered by the library and on this base develop some guidelines for user involvement. Finally, the last section presents some concluding remarks.

\section{Theoretical Background}

\subsection{Understanding Face to Face and E-Services}

According to Bitner et al. (2008), one of the most distinctive characteristics of services is their process nature. Unlike physical goods, services are dynamic and unfold over a period of time through a sequence or constellation of events and steps. The service process can be viewed as a chain or constellation of activities that allow the service to function effectively (e.g. Shostack 1982; Shostack 1984). In contrast to goods, which can be separated from the immediate producers and sold on an anonymous market, services are not anonymous and are produced and consumed simultaneously (Bitner et al., 2008). Therefore, services require face-to-face contact between the producers and the consumers in the production/ consumption phase. This may not always hold entirely true, but the consumption will at least start right after the end of production - as in the case of repair work (Scupola et al., 2009).

In the last 2 decades or so, the advent of information and communication technology (ICT) and especially the World Wide Web has affected services in several ways and research has flourished on the subject of technology-based services, Internetbased services or e-services (see e.g. Bitner et al., 2000; Scupola et al., 2009). Especially in the case of information and knowledge services (informational services), it is the service itself which is affected. With ICTs, it is possible to enter data, information and knowledge (to the extent it can be codified) on digital media and use communication networks for transportation (Hofacker et al., 2007). This means that data, information or knowledge services increasingly can be separated from the immediate producers and sold on anonymous markets. It could therefore be claimed that there is a degree of convergence between goods and services enabled by the use of digital communications and that services in a sense become goods (Scupola et al., 2009). 


\subsection{The service innovation and design process}

One main characteristic of services is that the customer is essential in the service provision process, whether this process is face to face or Internet-based. However, while a lot of literature especially within the service marketing field has addressed customer involvement in the final act of service providing by focusing for example on the moment of truth, customer experience, or service co-creation (e.g. Padgett and Allen 1997), the concept of user involvement in the service innovation process and design is not a well-defined concept despite the fact that much has been written about it (Magnusson et al., 2003).

A broad applied way to understand service innovation is to analyze the different phases or steps of the innovation process (Cooper et al., 2002). In order to do so, this paper draws on the service innovation model developed by Alam and Perry (2002) characterized by 10 steps: 1) Strategic planning; 2) Idea generation; 3) Idea screening; 4) Business analysis; 5) Formation of cross-functional team ; 6) Service and process design ; 7) Personnel training ; 8) Service testing and pilot run; 9) Test marketing; 10) Commercialization. This model takes into account the core element in user involvement in new service development highlighting the objective/purpose of involvement, the stages of involvement in the organizational innovation process, the intensity of involvement and the modes of involvement.

\subsection{The user roles}

Nambisan (2002) has developed three roles that customers can have in new product development: "customer as a resource", "customer as co-creator" and "customer as user". More recently Scupola and Nicolajsen (2010) and Nicolajsen and Scupola (2011) have showed that the roles developed by Nambisan (2002) in the context of New Product Development, can also be applied in the context of new service development. The role of the customer as a resource in the phases of generating new product ideas has been extensively investigated by the marketing and innovation literature (e.g. von Hippel, 2001). According to Nambisan (2002), the contribution of customers as a resource varies with the maturity of the technology and the alignment of the product line with the customer base. In the case of continuous innovations, customers are generally passive and firms have to find out about the customers opinion through market surveys or focus groups. Previous literature (e.g. von Hippel, 2001; Matthing et al., 2004) also argue that there are a number of challenges related to using customers as a resource in idea generation including selection of customers, creation of incentives to foster customer participation and capture of customer knowledge.

Customers may also play a key role as co-creators of new products or services. As co-creators, customers can participate in a number of activities varying from design activities to development activities. According to Nambisan (2002, p. 396) customerfirms interactions tend to be much more intense and frequent during co-creation, and mechanisms to support such interactions are costly and technology intensive. Similarly, Alam $(2002 ; 2006)$ found that the stages where customers' involvement was valuable were much more expensive, time-consuming, more cumbersome and risky in terms of return on investment.

The last role that Nambisan (2002) has identified is the customer as a user. In such a role customers can provide value in two ways in the service process: service testing and support. For example in the software industry many firms have used their cus- 
tomers in beta product testing, thus enabling those firms to reduce their investments in internal product testing units. For example, the involvement of users in product testing can be used to identify problems early on in the development phase, thus minimizing the costs of redesign and re-development.

\subsection{Tools for user driven service innovation and design}

Previous literature has distinguished the tools that can be used to involve users in the design process into face to face and virtual (ICT-based) tools (e.g. Prandelli, Sawhney and Verona, 2008; Scupola and Nicolajsen, 2013). One of the most used face-to-face methods to involve users in service design and innovation is workshops (see e.g. Bitner et al. 2008; Alam, 2002). Examples of ICT-based tools that are becoming more and more important are social media (e.g. Facebook, twitter, blogs), online surveys, user toolkits (e.g. Franke and Piller, 2004) and online idea competitions and forums.

\section{User Involvement in Practice: The case of Roskilde University Library}

In order to illustrate how users can be involved in different stages of the service innovation process in practice, here an in-depth case study of Roskilde University Library is presented (Yin, 1994). In this case study, the author (together with 2 more colleagues) acted as facilitators to develop service innovations at the library following the experiment as research method (Sørensen et al. 2010). This kind of research method is in many ways similar to action research. The process consisted of three steps: 1) Uncovering current service innovation practices with focus on user involvement and tools at the library; 2) Applying ICT-based tools to involve users in the service innovation process; 3) Applying future workshops to generate ideas from employees, users and users-employees combined.

\subsection{First Phase- Uncovering current service innovation practices}

In the first phase, a study investigating current service innovation processes and sources of innovation with focus on user involvement at Roskilde University Library was conducted to get an understanding of the innovation processes at the library and especially to understand whether and how library users were involved in such a process. Semi-structured qualitative interviews as well as a number of meetings and workshops lasting between 1 and 2 hours with top managers, middle managers, and 'front-line' librarians were the main data collection methods used in the study. In this phase, the researchers acting as "external facilitators" had been the main agents collecting and analyzing the data and writing a report to the library management on the library current practices for service innovations as well the strategic need for new service innovations.

The results of this phase show that the library's traditional approach to innovation is mainly based on the use of 'internal development plans' where most ideas come from top management, collaboration with external partners and competitors but also, even though to a lesser extent, from employees. The study shows that traditionally the users had mainly taken on the "role as a resource" in the service innovation process and been involved mainly with tools such as surveys and customer complaints box. Web-based interactive tools had just recently been adopted at the library on an experimental basis to establish contact with users. This type of customer contact was just a 
virtual version of the face-to-face encounter and at the time of the study still limitedly used.

3.2 Second Phase - Using ICT-based tools to involve users in the process of service innovations

Given the results of the first phase indicating very limited customer involvement in the service innovation process, a decision was made by the library together with the team of researchers to use ICT-based tools to directly involve the users in the innovation process. Due to the library's previous experience with a blog used for internal organizational purposes, a decision was made to use a blog for collection of users' inputs. This process was initiated by the researchers, but it was run completely by the library and the ideas generated at the end of the process were analysed, ranked and selected for implementation by the library management.

\subsection{Third Phase- Using future workshops}

The third phase of the service innovation process consisted of three parallel future workshops organized by the researchers/facilitators aiming at involving users with face-to-face design tools in the idea generation and design process. The main purpose of this phase was to complement the ideas generated by the blog with new ideas generated through face-to-face complementary tools such as future workshops. One workshop was organized with only library employees in order to find out what the library employees believed was needed concerning service innovations, one was organized with only library users and a third one was organized with mixed participants, users and library employees. The workshops took place simultaneously at the library premises and were facilitated by the three researchers/facilitators. An announcement was put in the library looking for potential participants to the workshops. There were 6 participants in each workshop. A ticket to a movie theater was given to the workshop participants to increase motivation to participate. The workshops consisted of 3 different phases: a first phase in which the participants had to criticize the current library services, a creative phase where the participants had to come up with new service concepts/ideas and an implementation phase where the ideas had to be concretized into specific service designs. The researchers/facilitators recorded the ideas generated on post it, tape recorded the participants' discussions, and finally inserted the data collected in the three different workshops and different phases of the workshops in a spreadsheet. The ideas were then ranked for relevance, selected for implementation and finally implemented by the library management.

\subsection{Summary of Steps and Tools for User-driven service innovations}

Based on the phases and actions described above, a set of guidelines for user-driven service innovations and design are proposed here as follows and briefly summarized in Table 1.

1. Uncover current organizational practices and needs concerning service innovations and design. This can be done by using tools such as interviews, workshops, focus groups with key organizational employees. This phase should be conducted by a process facilitator, possibly external to the organization. This 
phase should identify specific areas to focus later actions and service innovation efforts on. Go to 2 or 3 , but possibly conduct both phase 2 and 3 .

2. Identify a suitable form of ICT-based tools to generate ideas from the organization's users on service innovations and to the extent possible from external partners. Go to 4 and possibly 3 .

3. Organize (future) workshops to elicit further ideas for service innovations and design involving users, but also employees. The different workshops could take the following forms: a) A workshop where the participants are only employees from the organization; b) A workshop where the participants are only users of the services; a workshop where both users and organizational employees participate. Go to 4 and 2 if it has not been conducted yet.

4. Have organizational meetings to evaluate the ideas generated in step 2 and 3 . Go to 5 .

5. Implement the service innovations found important in step 4. Go to 6 .

6. Communicate to the stakeholders involved in the process (users, employees and, eventually, other partners) which service innovations/changes were implemented and why.

Table 1: Guidelines for user driven service innovation and design

\begin{tabular}{|l|l|}
\hline Steps & Actions \\
\hline Step 1 & $\begin{array}{l}\text { Uncover current service innovation } \\
\text { practices and needs in the organization }\end{array}$ \\
\hline Step 2 & $\begin{array}{l}\text { Use ICT-based tools to involve users } \\
\text { in the generation of ideas for service } \\
\text { innovations }\end{array}$ \\
\hline Step 3 & $\begin{array}{l}\text { Use face-to-face tools to generate ide- } \\
\text { as for service innovations with user in- } \\
\text { volvement }\end{array}$ \\
\hline Step 4 & $\begin{array}{l}\text { Evaluation of the collected ideas } \\
\text { Implementation of the ideas }\end{array}$ \\
\hline Step 6 5 & $\begin{array}{l}\text { Provide feedback to the involved } \\
\text { stakeholders in the process about the re- } \\
\text { sults of the service innovation process }\end{array}$ \\
\hline
\end{tabular}

\section{Conclusions}

By taking the starting point in theories of user involvement and user roles in service innovations and their application in an in depth case study, this paper has presented some guidelines for user driven service innovations. These guidelines are presented in the form of a series of steps and actions. The paper contributes to theory of service innovation by illustrating how to involve users in the service innovation process by means of both face-to-face and ICT-based tools in a specific case setting and by providing some simple guidelines. The contribution of the paper to practice is that practitioners can consider and eventually use such guidelines to more systematically involve users in service innovation and design processes. These guidelines are im- 
portant because they provide a series of actions specifying what to do in order to develop service innovations with the involvement of the customer or user. Such actions might guide the service innovation process and can be used as the basis for the choice of the tools to be used in each step of such process.

Finally the article is not free of limitations. First of all, the provided guidelines are very simple and basic and are based on a single case study. Therefore, they have to be taken with caution. Secondly, the experiment lasted a relatively short period of time and the number of workshops was also limited. Nevertheless, the article provides some insights on how to proceed to involve users in the service innovation and design process, which might be useful to innovation researchers and practitioners alike.

\section{References}

Alam, I. and Perry, C: A customer-oriented new service development process. Journal of Services Marketing 16 (6), no. 6, 515-534, (2002).

Alam I: Removing the fuzziness form the fuzzy front-end of service innovations through customer interactions. Industrial Marketing Management (35), (2006), 468480.

Alam, I: An exploratory investigation of user involvement in new service development. Journal of the Academy of Marketing Science, 30 (3), 250-26, (2002).

Bitner, M.J., Ostrom, A.L., Morgan, F.N: Service Blueprinting: A Practical Technique for Service Innovation. California Management Review, (2008).

Bitner, M.J., Brown, S.W., Meuter, M.L.: Technology infusion in service encounter. Journal of the Academy of Marketing Science, 28, no. 1,138-149, (2000).

Cooper, R., Edgett, G., Scott J., Kleinschmidt, E.J.: Organizing the stage-gate process: What best-practice companies do-II. Research technology management, 45(6), 43-50, 2002.

Franke, N., Piller, F.: Value creation by toolkits for user innovation and design: the case of the watch market. Journal of product innovation management, (21) 401-415, (2004)

Hofacker, C.F., Goldsmith, R.E., Bridges, E., Swilley, E: E-Services: A Synthesis and Research Agenda. Journal of Value Chain Management, 1(1/2), no. 1/2, 13-34, (2007).

Magnusson, P., Matthing, J., Kristensson, P: Managing user involvement in service innovation. Journal of Service Research, 6, no. 2,111-124, 2003.

Matthing, J., Sandén, B., Edvardsson, B.: New service development: learning from and with customers. International Journal of Service Industry Management, 15, no. 5, 479-498, 2004.

Nambisan, S.: Designing virtual customer environments for new product development: Toward a theory. The Academy of Management Review, 27, no. 33, 392-413 (2002).

Nicolajsen, Westh, H., Scupola, A.: Investigating issues and challenges for customer involvement in Business services innovation. Journal of Business and Industrial Marketing, 26, no. 5, 368 - 376, 2011.

Nicolajsen, H.W., Scupola, A.: KIBS and Their Users as Co-creators of Breakthrough Innovations, in "User-Based Innovation in Services", Sundbo, J. and Toivoneen, M. (Eds.), pp. 101-120, Edward Elgar Hardback, 2011. 
Prandelli, E., Sawhney, M., Verona, G.: Collaborating with customers to innovate, Edward Elgar, UK, 2008.

Scupola, A., Henten, A., Nicolajsen, Westh, H.: E-services: Characteristics, Scope and Conceptual Strengths. International Journal of E-Services and Mobile Applications, Vol. 1, no. 3, 1-16, 2009.

Scupola, A., Nicolajsen, Westh, H.: Service Innovation In Academic Libraries: Is There a Place for the Customers?. Library Management, 31, no. 4/5, 304-318, Emerald, 2010.

Scupola, A., Nicolajsen, Westh H.: Blogs and User Involvement in the Service Innovation Process: Challenges and Pitfalls. International Journal of E-Business Research, Vol. 9, No. 3, 27-37, 2013.

Shostack, G.L.: How to Design a Service, European Journal of Marketing, 16(1), 49 63, 1982.

Shostack, G. L.: Service positioning through structural change. Journal of Marketing, 51(1), 34-34,1984.

Sørensen, F., Mattsson, J., Sundbo, J.: Experimental Methods in Innovation Research, Research Policy, Vol 39, no. 3, pp. 313-322, 2010.

Yin, R. K.: Case Study Research Design and Methodology. Second Edition, Vol. 5, Sage Publications, 1994. 